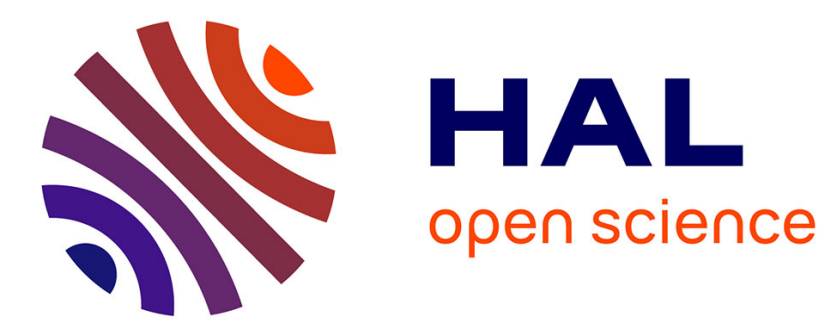

\title{
Overview of trace elements trophic transfer in fish through the concept of assimilation efficiency
}

Simon Pouil, Paco Bustamante, Michel Warnau, Marc Metian

\section{To cite this version:}

Simon Pouil, Paco Bustamante, Michel Warnau, Marc Metian. Overview of trace elements trophic transfer in fish through the concept of assimilation efficiency. Marine Ecology Progress Series, 2018, 588, pp.243-254. 10.3354/meps12452 . hal-02051715

\section{HAL Id: hal-02051715 https://hal.science/hal-02051715}

Submitted on 28 Feb 2019

HAL is a multi-disciplinary open access archive for the deposit and dissemination of scientific research documents, whether they are published or not. The documents may come from teaching and research institutions in France or abroad, or from public or private research centers.
L'archive ouverte pluridisciplinaire HAL, est destinée au dépôt et à la diffusion de documents scientifiques de niveau recherche, publiés ou non, émanant des établissements d'enseignement et de recherche français ou étrangers, des laboratoires publics ou privés. 


\section{Overview of trace elements trophic transfer in fish through the concept of}

assimilation efficiency

Simon Pouil ${ }^{\mathrm{a}, \mathrm{b}^{*}}$, Paco Bustamante ${ }^{\mathrm{b}}$, Michel Warnau ${ }^{\mathrm{a}, \mathrm{c}}$, Marc Metian $^{\mathrm{a}}$

a International Atomic Energy Agency, Radioecology Laboratory - Environment Laboratories, 4a, Quai Antoine Ier, MC-98000, Principality of Monaco, Monaco

b Littoral Environnement et Sociétés (LIENSs), UMR 7266, CNRS-Université de La Rochelle, 2 rue Olympe de Gouges, F-17000 La Rochelle, France

c Technical Cooperation Department, International Atomic Energy Agency, Vienna, Austria

* Corresponding author: Simon Pouil

ORCID: 0000-0003-1531-0362

Radioecology Laboratory

IAEA Environment Laboratories

4a Quai Antoine 1er

MC-98000 Principality of Monaco

Telephone: +3779797 7217

E-mail: simon.pouil1@gmail.com 


\begin{abstract}
:
Among the different accumulation pathways of trace elements, water has initially retained the attention of the scientific studies on fish but the trophic transfer gradually gained considerations for now being generally identified as the major contribution pathway for trace element intake. The experimental approach is currently the most appropriate way to precisely quantify the trophic transfer of trace elements in fish. Thus, the assimilation efficiency (AE) of trace elements from ingested food is a commonly-determined parameter. However, there are still some discrepancies in the literature regarding the definition and the determination of $\mathrm{AE}$ in aquatic organisms and especially in fish. In this context, this review gathers the information about this concept as well as a description of the methods and protocols used to quantify the AE of trace elements thanks to experimental studies. It also looks over the main results concerning trace element $\mathrm{AE}$ in fish from the available literature. Most studies reporting $\mathrm{AE}$ considered the effects of biotic factors, especially the influence of the quality of the food. Abiotic factors have received less attention although they affect fish physiology and by extension potentially affect $\mathrm{AE}$ of trace elements. The need for further investigations is thus rising from the review, especially looking at the influence of abiotic factors such as temperature, salinity or $\mathrm{pH}$ on trace element $\mathrm{AE}$ or in the context of multiple stressors co-occurrence; this will help the better understanding trophic transfer of trace elements in fish and thus the overall their bioaccumulation in fish.
\end{abstract}

Keywords: Assimilation efficiency, Fish, Food, Metals, Experimental studies 


\section{INTRODUCTION}

In the field of ecotoxicology, the first use of fish in scientific studies originated in the 1930s with the purpose of testing the effect of various chemicals on them, including toxic trace elements usually released in aquatic environments by anthropogenic activities (Valavanidis and Vlachogianni 2010). Since then, fish have proved their suitability for ecotoxicological studies (Braunbeck et al. 1998) given their broad species diversity, the wide range of diets (from algae to other fish) and their broad geographical distribution in various environments. Furthermore, the relevance of fish in ecotoxicology is also connected to their ecological and economic importance (Holmlund and Hammer 1999; Tidwell and Allan 2001).

Fish accumulate trace elements through both the dissolved and particulate pathways but the diet appears to be the predominant source for a series of elements (Xu and Wang 2002; Mathews and Fisher 2009). Therefore, understanding the trophic transfer of trace elements is a key aspect to assess the accumulation capacities in fish and their exposure to contaminants. Since distinction of the food contribution to the global bioaccumulation is complex to perform on individuals collected in the field, experimental approach appears to be the best option to assess unambiguously the trophic transfer of trace elements in fish (Wang and Fisher 1999).

One of the most relevant parameters to quantify trophic transfer of a contaminant its the assimilation efficiency (AE) from ingested food. AE is a first-order physiological parameter that can be quantitatively compared among trace elements, fish species, diets and environmental conditions (Wang and Fisher 1996; Croteau et al. 2007). Because dietary trace elements bioaccumulation is directly related to $\mathrm{AE}$, this parameter is important to understand and predict global trace elements uptake (Wang and Fisher 1996; Luoma and Rainbow 2005; Croteau et al. 2007). This parameter is thus widely used in modern ecotoxicological studies. However, the concept of AE appears sometimes unclear in the literature due to some discordances in the way it is defined. 
This review provides a general definition of the concept of $\mathrm{AE}$, critically examines the methodologies used for AE measurements in fish to date and discusses the recent improvements made on the different methods. It also extensively analyzes results of trace elements' AE in fish reported in the literature. This review finally presents a summary of perspectives for guiding future studies on the subjecting and in complements the review made 18 years ago on AE in invertebrates (Wang and Fisher 1999).

\section{The need to clearly define the concept of assimilation efficiency}

Assimilation efficiency (AE) is a physiological parameter determined to understand the trophic transfer of chemicals in organisms. However, as Wang and Fisher (1999) have already pointed out in their review, there are still discrepancies in experimental studies regarding the definition of the AE. According to these authors, "In bioenergetic studies, absorption of an element or compound equals total ingestion of the substance minus its quantity in faecal matter and is the sum of assimilation and post-digestive soluble excretion (i.e., loss of material into the dissolved phase after post-ingestive metabolism)". According to this definition, AE is the fraction of ingested element or compound that is incorporated into biological tissue, whereas absorption efficiency is the fraction of the ingested element or compound that passes through the gut epithelium by passive and active transports (Brett and Groves 1979; Penry 1998). Assimilation thus equals absorption minus defecation and excretion. This AE definition is in line with Warnau et al. (1996), which, in essence, indicates that the AE could be defined as the fraction of the ingested material that is tightly bound (i.e. incorporated) in the organs and tissues of a given organism. From a theoretical point of view, the difference between absorption and assimilation is obvious, but in practice, it is difficult to delineate quantitatively these two mechanisms at the whole-body level because during the gut transit, these physiological processes can occur at the same time. Thus, another physiological parameter is used to determine the required time to assess AE (e.g. Ni et al. 2000; Xu and Wang 2002): the gut 
transit time (GTT; i.e. duration that a food ration spends in the digestive tract between its ingestion and its defecation). Indeed, it is during that phase that the absorption of chemicals takes place. This method has some limitations which must be taken into account. Indeed, during the GTT, it is difficult to guaranty that only absorption of the ingested compounds takes place since excretion can also already intervene; hence a part of the absorbed fraction can be already excreted. Indeed, after intestinal absorption compounds such as trace elements are conveyed through the bloodstream to the liver and can be directly excreted via the biliary secretions discharged in the intestine or, latter through the gills and the urine (Wood 2011). Furthermore, there are some assumptions that egestion directly from the gut can occur through compounds secreted with digestive juices or sloughed inside detached enterocytes and then evacuated via the faeces or rectal fluid (Wood 2011). In addition, we assume that part of the non-assimilated fraction might remain a bit longer in the digestive tract, associated to the intestinal mucus that can play a regulatory role in the absorption of ingested elements such as trace elements (Warnau et al. 1996, Bury et al. 2003). This situation might thus impact the accuracy for determining AE. This fact raises the crucial importance of the design and duration of experiments (i.e. the duration of the feeding period and the time during which depuration will be followed after ingestion of food) in order to accurately determine $\mathrm{AE}$ (see also section 3.2.3).

\section{Determination of the assimilation efficiency in fish}

\subsection{Assimilation efficiency of macromolecules by fish}

Since AE of a given element or compound is defined as its absorption minus its excretion, it could be calculated as the difference between its quantity ingested (quantity presents in the food) minus quantity egested (quantity in the faeces). This method, the so-called mass-balance, has been used to study the AE of nutrients such as proteins and lipids in farmed fish. Using this method, AE can be calculated as follow: 


$$
\mathrm{AE}(\%)=\left(\frac{\text { ingested }- \text { fecal }}{\text { ingested }}\right) \times 100
$$

However, urinary and branchial excretions are not taken into account in this calculation, which limits its accuracy. Furthermore, to be efficient, the mass-balance approach requires to be able to get an accurate quantification of the studied compound in the food and faeces. Some challenges may appear at this stage such as the ability to collect the faeces before their complete or partial dissolution in the water, that could lead to the loss or partial loss of the studied element (Choubert 1999).

Another method, based on the same mass-balance principle, uses an inert tracer, such as chrome oxide $\mathrm{Cr}_{2} \mathrm{O}_{3}$ (Austreng 1978; Austreng et al. 2000), titanium oxide $\mathrm{TiO}_{2}$ (Weatherup and McCracken 1998; Vandenberg and De La Noüe 2001; Richter et al. 2003) or acid-insoluble ash (Sarker et al. 2016). Incorporated in the compounded feed or ingredients/constituents of the food matrix (Tacon and Rodrigues 1984; Morales et al. 1999), the inert tracer allows correcting AE measurement for possible post egestion loss. In this case, AE can be calculated using the following equation (Maynard and Loosli 1969):

$$
\mathrm{AE}(\%)=\left(\frac{\% \text { inert marker in the food }}{\% \text { inert marker in the feces }} \times \frac{\% \text { element in the feces }}{\% \text { element in the food }}\right) \times 100
$$

This ratio is widely used in aquaculture nutrition since it does not require a complete recovery of faeces, as it is the case for the original approach. Its use is nevertheless limited nowadays given the fact that the selected inert tracer/marker must fulfil several characteristics, which are not easily met. Indeed, the inert marker, in principle, should: (1) be absolutely inert, without physiological effect on fish; (2) not be absorbed or metabolized; (3) not influence absorption and/or digestion; (4) be easily and quickly measurable (Choubert 1999). To the best of our knowledge, no marker perfectly fits all these conditions at once. Furthermore, this method does not take into account urinary and branchial excretion. Despite some disadvantages, this method 
is however still used in aquaculture studies to determine the assimilation efficiency of macromolecules such as proteins and lipids in fish (e.g. Zhang et al. 2015; Sarker et al. 2016). With an increasing research interest in the trophic transfer of trace elements in fish, other methods for AE determination, developed specifically for these elements, have emerged.

\subsection{Assimilation efficiency of trace elements in fish}

\subsubsection{Use of radiotracers}

One of the most efficient method to determine AE of trace elements in fish is the use of radiotracers. As isotopes of a given share the same properties among each other, radioactive isotope of a trace element can be used as tracer of that element. Thus, the two approaches described in the previous section (mass-balance and ratio) can be applied in the determination of $\mathrm{AE}$ for trace elements, using radiotracers in aquatic organisms such as fish. For example, $\mathrm{Ni}$ et al. (2000) have already compared AE of $\mathrm{Cd}, \mathrm{Cr}$ and $\mathrm{Zn}$ in the mudskipper Periophthalmus modestus and the glassy Ambassis urotaenia obtained, using radiotracers with mass-balance and ratio approaches. In that study, the authors concluded that to two approaches give similar results. Since then, the ratio approach has not been tested again in the determination of trace element $\mathrm{AE}$ in fish.

In addition to the two previous methods, the use of radiotracers and particularly gammaemitting radiotracers allowed developing a new approach in the determination of the AE of trace elements: the pulse-chase feeding mathod. This technique has many advantages that explain its widespread use in the literature (e.g. Xu and Wang 2002; Wang et al. 2012; Pouil et al. 2016). The use of gamma-emitting radioisotopes allows radiocounting fish alive, thus limiting the number of individuals to sacrifice and generating data with reduced biological variability (Warnau and Bustamante 2007). In the pulse-chase feeding method, fish are fed with radiolabelled food (natural prey or compounded feeds) are radiocounted just after the radiolabelled feeding. Then, fish are regularly counted alive in order to describe the depuration 
kinetic of the radiotracers and, thereby, to determine the AE (see details in section 3.2.3). The determination of $\mathrm{AE}$ based on a kinetic approach is done from a unique feeding with a radiolabelled food item. The fish are allowed to feed on radiolabelled food for a short period of time (shorter than their GTT; usually from 5 min to $2 \mathrm{~h}$ ) to ensure that the radioactivity ingested can be accurately quantified without any possible radiotracer recycling from seawater due to leaching from the radiolabelled food, leading to an overestimation of AE. Recently, Pouil et al. (2017) provided an experimental validation of the single-feeding approach for the determination of $\mathrm{Co}, \mathrm{Cd}, \mathrm{Mn}$ and $\mathrm{Zn}$ AEs in the turbot Scophthalmus maximus fed with radiolabeled compounded food.

\subsubsection{Improvements in the AE calculation}

Two methods are commonly used to calculate trace element AE using gamma-emitters. For both methods, the proportion of trace elements retained in the fish during the depuration period is followed using regular gamma-countings of live organisms. In the first method, AE is determined at a given time and expressed as a percentage of trace element retained after the GTT from the total ingested fraction (e.g. Xu and Wang 2002; Van Campenhout et al. 2007; Goto and Wallace 2009). Usually, in this method, the depuration is followed over a short time (i.e. few hours or few days; Table 1); it provides therefore a rapid insight on the transfer of trace elements in fish from their food. The second method is based on the actual determination of the trace element depuration kinetics. This technique has been extensively used in radioecological studies and improved by the use of multi exponential models, which parameters are solved by iterative adjustment. Depuration of trace elements are typically expressed as the percentage of remaining radioactivity (radioactivity at time t divided by the initial radioactivity measured in the organism at the beginning of the depuration period*100). Depuration kinetics are genrally best fitted by a two-component exponential model: 


$$
A_{t}=A_{0 s} \times e^{-k_{e s} t}+A_{0 l} \times e^{-k_{e l} t}
$$

where $A_{t}$ and $A_{0}$ are the remaining activities (\%) at time $t(d)$ and 0 , respectively; $k_{e}$ is the depuration rate constant $\left(\mathrm{d}^{-1}\right)$. "s" and "l" subscripts are related to the short- and long-lived component, respectively. The "s" component represents the depuration of the radiotracer fraction that is weakly associated with the organisms and rapidly eliminated (i.e. proportion associated with the faeces). The "l" component describes the depuration of the radiotracer fraction that is actually absorbed by the organism and eliminated slowly (Hubbell et al. 1965; Reichle 1967; Reichle et al. 1970; Whicker and Schultz 1982; Warnau et al. 1996). The longlived component allows estimating the assimilation efficiency (AE), by calculating the y-axis intercept of the "l" component, of the radiotracer ingested with food (AE = $\mathrm{A}_{01}$; Reichle 1967; Fowler and Guary 1977; Miramand et al. 1982). In some studies, the depuration of the assimilated fraction of trace elements was shown to be very slow (e.g. Pouil et al. 2015; Pouil et al. 2016). When the long-term depuration rate constant $\left(k_{e l}\right)$ is not significantly different from 0 , the "l" component of the exponential model can therefore be simplified and replaced by a constant (e.g. Pouil et al. 2015; 2016) and the equation becomes:

$$
A_{t}=A_{0 s} \times e^{-k_{e s} t}+A_{01}
$$

with $\mathrm{A}_{01}=\mathrm{AE}$

This method requires that the fish be depurated for a sufficiently long period of time to get an accurate determination of the slope of the slowest depurating compartment. Usually, the depuration of the fish is followed for several weeks (Table 1). Because all the excretion processes (urinary, branchial and biliary) are taken into account, it is the most robust method to accurately determine AE (see section 3.2.3).

\subsubsection{How the duration of depuration influences AE determination}

In fish, the depuration can be usually described in three different phases. The first phase, usually 
few hours after the feeding, very rapid, corresponds to the passage of the ingested food from the stomach to the intestine where absorption process occurred (Baines et al. 2002; Dutton and Fisher 2011). The second phase, usually in the first week of depuration, is dominated by the occurrence of the absorption and rapid excretion processes (Baines et al. 2002; Dutton and Fisher 2011; Pouil et al. 2016). During phases 1 and 2, as shown by Pouil et al. (2017), almost all the trace elements ingested were distributed in the stomach and the intestine. Then, the third phase reflects the physiological turn-over from the slowest depurating compartment after absorption and excretion (Wang and Fisher 1999). The loss of trace elements during this phase is reduced and the body burden of trace elements is stabilizing. From a practical point of view, the duration of follow-up period of the depuration, defined by the experimenters, is therefore decisive to catch these biological processes. As explained in Section 2, GTT can be used to estimate the duration of the experiments in order to determine AE accurately. Some authors estimate the GTT by the frequent collection and the radiocounting of faeces subsequently to single-feeding and thus GTT ends at the moment when the last radioactive faeces have been collected (e.g. Ni et al. 2000). Thus, the duration of depuration is chosen to cover the GTT (i.e. in general from 24 to 72 hours in fish; e.g. Xu and Wang 2002; Van Campenhout et al. 2007; Goto and Wallace 2009). When depuration follow-up is made over a period close to GTT ("short-term" approach), AE is determined at a given time and expressed as a percentage of trace element retained. This approach does not allow taking into consideration the third phase depuration kinetics (i.e. when physiological turn-over occurs after absorption and excretion) as it is usually achievable when the duration of depuration extends over several weeks (i.e. "longterm" approach).

In order to compare AEs obtained using both "short-term" and "long-term" approaches, from data provided by Pouil et al. (2017b, supplementary material), statistical comparison (i.e. Wilcoxon-Mann-Whitney non-parametric test) was done on ${ }^{54} \mathrm{Mn}$ remaining activities at 
different times throughout a 21-d depuration in turbot Scophthalmus maximus fed with compounded pellets (Fig. 1). Remaining activities were stable from day 2 (i.e. less than $24 \mathrm{~h}$ after the GTT) up to day 21 after the beginning of the depuration ( $>>0.05)$. Nevertheless, statistical comparison between individual AE estimated as the percentage of remaining activity after 2 days ("short-term" approach) and individual AE obtained by fitting a model (i.e. "longterm" approach) indicated a significant overestimation of AE by "short-term" approach $(\mathrm{p}=0.04)$. This example shows that, on a given dataset, "short-term" and "long-term" approaches may lead to different AE estimations. Such bias can be avoided using a sufficiently long period of depuration that encompasses both the absorption and the excretion processes and allows an accurate delineation of the AE. In the "short-term depuration" approach, a part of the excretion processes occurring during the last phase of the depuration are assumed negligible, which is obviously not correct. Therefore, this approach can only be considered after a careful investigation of the depuration processes in given experimental conditions.

\section{Review of trace element assimilation efficiencies in fish}

\subsection{Results of AE related to trace elements and depuration duration}

Figure 2 shows reported range of AEs of different essential (i.e. metabolically required) and non-essential (no biological role) elements in fish. This overview of results from 35 experimental studies reveals that the findings regarding trace element $\mathrm{AE}$ are overall similar regardless of the method of determination (i.e. "short-term" and "long-term" approaches, Fig $2 \mathrm{~A}$ and $2 \mathrm{~B}$ ). However, using $\mathrm{Zn}$, one of the most studied elements, an analysis of the coefficients of variation (i.e. allowing to estimate the dispersion of the values from the average) for AE values reveals that the "short-term" approach leads to a higher AE variability than the "long-term" approach. This analysis provides an overall picture of AE variability according to the approach adopted for its determination. These findings, however, must be nuanced by the fact that other experimental factors that can also affect the AE variability (e.g. objectives of the 
study, number of organisms, etc.) are not taken account.

Non-essential elements, such as $\mathrm{Ag}, \mathrm{Am}, \mathrm{Cd}, \mathrm{Cs}, \mathrm{Hg}(\mathrm{II}), \mathrm{MeHg}$ and Po, are the most studied trace elements with, in particular, Cd AE values available for 15 species of fish (Fig. 2, Table 1). Among the 7 studied essential elements: $\mathrm{As}, \mathrm{Co}, \mathrm{Cu}, \mathrm{Cr}, \mathrm{Mn}, \mathrm{Se}$, and $\mathrm{Zn}$, the latter element is the one with the most AEs values available (more than 180 data expressed as Means \pm SD). The analysis of the AEs for the different trace elements shows that there is no obvious relation between the essential character of a trace element and its assimilation by the fish, in contrast to what has been observed in invertebrates (Wang and Fisher 1999). Interestingly, the trace elements with the highest $\mathrm{AEs}$ are $\mathrm{MeHg}$ and $\mathrm{Cs}$, which are both non-essential elements very efficiently assimilated by fish. These high AEs values explain for a large part why $\mathrm{Hg}$ and $\mathrm{Cs}$ biomagnify in aquatic food webs in both freshwater and marine ecosystems (e.g., GarnierLaplace et al. 2000; Zhao et al. 2001; Harmelin-Vivien et al. 2012; Lavoie et al. 2013; Pan and Wang 2016). Among the most efficiently assimilated elements, Se is an essential trace element known to have an antagonistic action with $\mathrm{Hg}$ in aquatic organisms (Belzile et al. 2006). Thus, field investigations have shown that high Se concentrations may force a preferential assimilation of this element over $\mathrm{Hg}$ through a competitive adsorption on binding sites. The occurrence of Se at high concentrations may also restricts the solubility and bioavailability of $\mathrm{Hg}$ to aquatic organisms or reduce it methylation in freshwater ecosystems (Cuvin-Aralar and Furness 1991; Belzile et al. 2006; Yang et al. 2008). To the best of our knowledge, no experimental study has investigated such effect in fish.

\subsection{Factors influencing trace element AEs in fish}

In theory, AE can be influenced by both abiotic and biotic factors because the latter factors potentially affect fish physiology and bioavailability of, or bioaccessibility to trace elements. The biotic factors have been the most studied in the literature (Fig. 3). The AE of trace elements in fish depends on the relation between the prey and their predators (Fig .3). Thus, it is possible 
to distinguish two types of biotic factors: those related to prey and those related to predators. Numerous studies have investigated the influence of food quality (type of natural prey and compounded food) on AE in fish. Several studies have shown that, in the same predator species, AEs can be very different depending on the type of food ingested (e.g. Dutton and Fisher 2011; Wang et al. 2012; Pouil et al. 2016). By a mechanistic approach, some authors have studied the factors related to the prey (i.e. bivalves and oligochaetes) that could explain these differences. In particular, based on studies initiated with invertebrates (i.e. crustaceans, Wallace and Lopez 1996; Wallace and Luoma 2003), the relationship between subcellular fraction of trace elements in food and AE observed in predators has been investigated in several species (Dang and Wang 2010, Zhang and Wang 2006). However, the results of these studies are contrasted. Some studies highlighted a positive relation between the cytosolic fractionation of $\mathrm{Cd}, \mathrm{MeHg}, \mathrm{Se}$, and $\mathrm{Zn}$ in the prey and the AEs of these elements in different species of fish (Seebaugh et al. 2005; Zhang and Wang 2006; Dang and Wang 2010). However, more recently, Pouil et al. (2016) have shown that no obvious relationship was observed for essential elements (Co, Mn, and $\mathrm{Zn})$ in juvenile Scophthalmus maximus fed more complex food matrices (complex pluricellular natural prey).

Interspecific comparisons of trace element AEs have also been made (e.g. Ni et al. 2000, Pouil et al. 2017a). The differences observed were often related to the trophic ecology of the organisms or their phylogeny. The influence of the predator size (i.e. allometry) on their AE was also investigated in black seabream Acanthopagrus schlegeli (Zhang and Wang 2007). In this study, Cd AE was independent of body size, whereas Se and $\mathrm{Zn}$ AE increased with the predator size. Regarding the feeding behavior of predators, although this parameter appears to be important in the understanding of trace element assimilation, there are still only few studies that have tackled this aspect. Among these, Van Campenhout et al. (2007) demonstrated in common carp Cyprinus carpio that frequency and rate of ingestion have a significant impact on 
the $\mathrm{AE}$ for $\mathrm{Cd}$ and $\mathrm{Zn}$. In the same study, the influence of water temperature on $\mathrm{AE}$ has also been investigated. Authors observed that decreasing the temperature from $25^{\circ} \mathrm{C}$ to $15^{\circ} \mathrm{C}$ did not influence $\mathrm{Cd} \mathrm{AE}$, while a significant decrease of $\mathrm{Zn} \mathrm{AE}$ was measured. The influence of trace element concentrations in the environment on $\mathrm{AE}$ in fish has been considered in few studies. It was for instance shown that Ag AEs were higher in waters highly contaminated by this element (Long and Wang 2005b; Boyle et al. 2011). However, no effect was observed for Cd or Zn (Zhang and Wang 2005; Boyle et al. 2011). Besides temperature or element concentrations, there is still a lack of knowledge regarding the possible effects of other abiotic factors on AE in fish.

Salinity, which is a key parameter in brackish and marine environments that influences both bioavailability of trace elements and fish physiology, has been investigated only in fish by $\mathrm{Ni}$ et al. (2005). These authors found no significant differences in $\mathrm{Cd}$, Se, and $\mathrm{Zn}$ AEs in Periophthalmus modestus acclimated from 10 to 30 psu. Recently, environmental pH, known to influence the digestive physiology of fish (Zhang and Wang 2006; Dang and Wang 2010), was considered to explore the possible effects of ocean acidification on stomach $\mathrm{pH}$ and the assimilation of essential elements (Co, Mn, and $\mathrm{Zn}$ ) in the clownfish Amphiprion ocellaris (Jacob et al. 2017). Another study investigated the influence of $\mathrm{pH}$ and temperature on the AE of Ag, Co, and Zn in turbot Scophthalmus maximus (Pouil et al. 2017b). These studies showed no significant effect of environmental $\mathrm{pH}$.

\section{Conclusion}

$\mathrm{AE}$ is a key parameter in the trophic transfer of trace elements in fish and is therefore widely investigated in ecotoxicology and aquaculture research. Despite it is intensively used, there are still divergences in the definition of the AE concept, as highlighted in this review, which may affect its experimental determination. Thus, we provided a critical analysis of the methods used 
to determine $\mathrm{AE}$ in fish in order to provide guidance for further studies. In complement, the emphasis on trace element $\mathrm{AE}$ in fish reveals that among the 35 experimental studies identified from the available open literature, the influence of environmental variables in the trophic transfer of these elements has received little attention. This research topic continues to offer exciting and challenging scientific questions for ecotoxicology and fish nutrition research.

\section{Acknowledgments}

The International Atomic Energy Agency (IAEA) is grateful to the Government of the Principality of Monaco for the support provided to its Environment Laboratories. M.W. is an Honorary Senior Research Associate of the National Fund for Scientific Research (NFSR, Belgium). The Institut Universitaire de France (IUF) is acknowledged for its support to P.B. Thanks also to Peter Swarzenski for helpful comments which improved the presentation of this work.

\section{References}

Austreng E (1978) Digestibility determination in fish using chromic oxide marking and analysis of contents from different segments of the gastrointestinal tract. Aquaculture 13:265-272 Austreng E, Storebakken T, Thomassen MS, Refstie S, Thomassen Y (2000) Evaluation of selected trivalent metal oxides as inert markers used to estimate apparent digestibility in salmonids. Aquaculture 188:65-78

Baines SB, Fisher NS, Stewart R (2002) Assimilation and retention of selenium and other trace elements from crustacean food by juvenile striped bass (Morone saxatilis). Limnol Oceanogr 47:646-655

Belzile N, Chen Y-W, Gunn JM, Tong J, Alarie Y, Delonchamp T, Lang C-Y (2006) The effect of selenium on mercury assimilation by freshwater organisms. Can J Fish Aquat Sci 63:110

Boyle D, Hogstrand C, Bury NR (2011) Physiological response to a metal-contaminated invertebrate diet in zebrafish: Importance of metal speciation and regulation of metal transport pathways. Aquat Toxicol 105:21-28 
Braunbeck T, Hinton DE, Streit B (1998) Fish Ecotoxicology. Springer Science \& Business Media, Berlin, Germany

Brett JR, Groves TDD (1979) Physiological Energetics. In: W.S. Hoar DJR and JRB (ed) Fish Physiology. Academic Press, pp 279-352

Bury NR, Walker PA, Glover CN (2003) Nutritive metal uptake in teleost fish. J Exp Biol 206:11-23

Calow P, Fletcher CR (1972) A new radiotracer technique involving ${ }^{14} \mathrm{C}$ and ${ }^{51} \mathrm{Cr}$, for estimating the assimilation efficiencies of aquatic, primary consumers. Oecologia 9:155170

Chan SM, Wang W-X, Ni I-H (2003) The uptake of Cd, Cr, and Zn by the macroalga Enteromorpha crinita and subsequent transfer to the marine herbivorous rabbitfish, Siganus canaliculatus. Arch Environ Contam Toxicol 44:0298-0306

Choubert G (1999) La digestibilité des nutriments chez les poissons : Aspects de méthodologie (in french). Cybium 23:113-125

Croteau M-N, Luoma SN, Pellet B (2007) Determining metal assimilation efficiency in aquatic invertebrates using enriched stable metal isotope tracers. Aquat Toxicol Amst Neth $83: 116-125$

Cuvin-Aralar ML, Furness RW (1991) Mercury and selenium interaction: A review.

Ecotoxicol Environ Saf 21:348-364

Dang F, Wang W-X (2010) Subcellular controls of mercury trophic transfer to a marine fish. Aquat Toxicol Amst Neth 99:500-506

Dutton J, Fisher NS (2011) Bioaccumulation of As, Cd, Cr, Hg (II), and MeHg in killifish (Fundulus heteroclitus) from amphipod and worm prey. Sci Total Environ 409:34383447

Fowler SW, Guary J-C (1977) High absorption efficiency for ingested plutonium in crabs. Nature 266:827-828

Garnier-Laplace J, Adam C, Baudin JP (2000) Experimental kinetic rates of food-chain and waterborne radionuclide transfer to freshwater fish: A basis for the construction of fish contamination charts. Arch Environ Contam Toxicol 39:133-144

Goto D, Wallace WG (2009) Influences of prey-and predator-dependent processes on cadmium and methylmercury trophic transfer to mummichogs (Fundulus heteroclitus). Can J Fish Aquat Sci 66:836-846

Harmelin-Vivien M, Bodiguel X, Charmasson S, Loizeau V, Mellon-Duval C, Tronczyński J, Cossa D (2012) Differential biomagnification of PCB, PBDE, Hg and radiocesium in the 
food web of the European hake from the NW Mediterranean. Mar Pollut Bull 64:974983

Holmlund CM, Hammer M (1999) Ecosystem services generated by fish populations. Ecol Econ 29:253-268

Hubbell SP, Sikora A, Paris OH (1965) Radiotracer, gravimetric and calorimetric studies of ingestion and assimilation rates of an isopod. Health Phys 11:1485-1501

Jacob H, Pouil S, Lecchini D, Oberhänsli F, Swarzenski P, Metian M (in press) Trophic transfer of essential elements in the clownfish Amphiprion ocellaris in the context of ocean acidification. PloS ONE

Lavoie RA, Jardine TD, Chumchal MM, Kidd KA, LM Campbell (2013) Biomagnification of mercury in aquatic food webs: a worldwide meta-analysis. Environ Sci Technol 47:13385-13394

Leaner JJ, Mason RP (2002) Factors controlling the bioavailability of ingested methylmercury to channel catfish and Atlantic sturgeon. Environ Sci Technol 36:5124-5129

Liu X-J, Ni I-H, Wang W-X (2002) Trophic transfer of heavy metals from freshwater zooplankton Daphnia magna to zebrafish Danio reiro. Water Res 36:4563-4569

Long A, Wang W-X (2005a) Metallothionein induction and bioaccumulation kinetics of Cd and Ag in the marine fish Terapon jarbua challenged with dietary or waterborne Ag and Cu. Mar Ecol Prog Ser 291:215-226

Long A, Wang W-X (2005b) Assimilation and bioconcentration of Ag and Cd by the marine black bream after waterborne and dietary metal exposure. Environ Toxicol Chem SETAC 24:709-716

Luoma SN, Rainbow PS (2005) Why is metal bioaccumulation so variable? Biodynamics as a unifying concept. Environ Sci Technol 39:1921-1931

Mathews T, Fisher NS (2009) Dominance of dietary intake of metals in marine elasmobranch and teleost fish. Sci Total Environ 407:5156-5161

Mathews T, Fisher NS (2008) Trophic transfer of seven trace metals in a four-step marine food chain. Mar Ecol Prog Ser 367:23-33

Mathews T, Fisher NS, Jeffree RA, Teyssié J-L (2008) Assimilation and retention of metals in teleost and elasmobranch fishes following dietary exposure. Mar Ecol Prog Ser 360:1-12

Maynard LA, Loosli JK (1969) Animal nutrition, 6st Edition. McGraw-Hill, New York, USA

Miramand P, Fowler SW, Guary JC (1982) Comparative study of vanadium biokinetics in three species of echinoderms. Mar Biol 67:127-134 
Morales AE, Cardenete G, Sanz A, De la Higuera M (1999) Re-evaluation of crude fibre and acid-insoluble ash as inert markers, alternative to chromic oxide, in digestibility studies with rainbow trout (Oncorhynchus mykiss). Aquaculture 179:71-79

Ni I-H, Wang W-X, YIN KT (2000) Transfer of Cd, Cr and Zn from zooplankton prey to mudskipper Periophthalmus cantonensis and glassy Ambassis urotaenia fishes. Mar Ecol Prog Ser 194:203-210

Pan K, Wang W-X (2016) Radiocesium uptake, trophic transfer, and exposure in three estuarine fish with contrasting feeding habits. Chemosphere 163:499-507

Penry DL (1998) Applications of efficiency measurements in bioaccumulation studies: Definitions, clarifications, and a critique of methods. Environ Toxicol Chem 17:16331639

Pickhardt PC, Stepanova M, Fisher NS (2006) Contrasting uptake routes and tissue distributions of inorganic and methylmercury in mosquitofish (Gambusia affinis) and redear sunfish (Lepomis microlophus). Environ Toxicol Chem 25:2132-2142

Pouil S, Oberhänsli F, Bustamante P, Metian M (in press) Investigations of temperature and pH variations on metal trophic transfer in turbot (Scophthalmus maximus) fish. Environ Sci Pollut R. doi:10.1007/s11356-017-8691-4

Pouil S, Teyssié J-L, Rouleau C, Fowler SW, Metian M, Bustamante P, Warnau M (2017) Comparative study of trophic transfer of the essential metals Co and $\mathrm{Zn}$ in two tropical fish: A radiotracer approach. J Exp Mar Biol Ecol 486:42-51

Pouil S, Warnau M, Oberhänsli F, Teyssié J-L, Bustamante P, Metian M (2017) Comparing single-feeding and multi-feeding approaches for experimentally assessing trophic transfer of metals in fish. Environ Toxicol Chem 36:1227-1234

Pouil S, Warnau M, Oberhänsli F, Teyssié J-L, Bustamante P, Metian M (2016) Influence of food on the assimilation of essential elements (Co, Mn, and $\mathrm{Zn}$ ) by turbot Scophthalmus maximus. Mar Ecol Prog Ser 550:207-218

Pouil S, Warnau M, Oberhänsli F, Teyssié J-L, Metian M (2015) Trophic transfer of ${ }^{110 \mathrm{~m}} \mathrm{Ag}$ in the turbot Scophthalmus maximus through natural prey and compounded feed. J Environ Radioact 150:189-194

Rainbow PS, Luoma SN, Wang W-X (2011) Trophically available metal: A variable feast. Environ Pollut 159:2347-2349

Reichle DE (1967) Radioisotope turnover and energy flow in terrestrial isopod populations. Ecology 48:351-366 
Reichle DE, Dunaway PB, Nelson DJ (1970) Turnover and concentration of radionuclides in food chains. Nucl Saf 11:43-45

Reinfelder JR, Fisher NS (1994) Retention of elements absorbed by juvenile fish (Menidia menidia, Menidia beryllina) from zooplankton prey. Limnol Oceanogr 39:1783-1789

Richter H, Lückstädt C, Focken U, Becker K (2003) Evacuation of pelleted feed and the suitability of titanium (IV) oxide as a feed marker for gut kinetics in Nile tilapia. J Fish Biol 63:1080-1099

Sarker PK, Gamble MM, Kelson S, Kapuscinski AR (2016) Nile tilapia (Oreochromis niloticus) show high digestibility of lipid and fatty acids from marine Schizochytrium sp. and of protein and essential amino acids from freshwater Spirulina sp. feed ingredients. Aquac Nutr 22:109-119.

Seebaugh DR, Goto D, Wallace WG (2005) Bioenhancement of cadmium transfer along a multi-level food chain. Mar Environ Res 59:473-491

Tacon AGJ, Rodrigues AMP (1984) Comparison of chromic oxide, crude fibre, polyethylene and acid-insoluble ash as dietary markers for the estimation of apparent digestibility coefficients in rainbow trout. Aquaculture 43:391-399

Tidwell JH, Allan GL (2001) Fish as food: aquaculture's contribution. EMBO Rep 2:958-963

Valavanidis A, Vlachogianni T (2010) Metal pollution in ecosystems, ecotoxicology studies and risk assessment in the marine environment. Sci Adv Environ Toxicol Ecot Issues

Van Campenhout K, Bervoets L, Blust R (2007) Assimilation efficiencies of Cd and Zn in the common carp (Cyprinus carpio): effects of metal concentration, temperature and prey type. Environ Pollut Barking Essex 1987 145:905-914

Vandenberg GW, De La Noüe J (2001) Apparent digestibility comparison in rainbow trout (Oncorhynchus mykiss) assessed using three methods of faeces collection and three digestibility markers. Aquac Nutr 7:237-245

Wallace WG, Lopez GR (1996) Relationship between subcellular cadmium distribution in prey and cadmium trophic transfer to a predator. Estuaries 19:923-930

Wallace WG, Luoma SN (2003) Subcellular compartmentalization of Cd and Zn in two bivalves. II. Significance of trophically available metal (TAM). Mar Ecol Prog Ser 257:125-137

Wang W-X, Fisher NS (1999) Assimilation efficiencies of chemical contaminants in aquatic invertebrates: a synthesis. Environ Toxicol Chem 18:2034-2045

Wang W-X, Fisher NS (1996) Assimilation of trace elements and carbon by the mussel Mytilus edulis: effects of food composition. Limnol Oceanogr 41:197-207 
Wang W-X, Onsanit S, Dang F (2012) Dietary bioavailability of cadmium, inorganic mercury, and zinc to a marine fish: effects of food composition and type. Aquaculture 356-357:98104

Wang W-X, Wong RS (2003) Bioaccumulation kinetics and exposure pathways of inorganic mercury and methylmercury in a marine fish, the sweetlips Plectorhinchus gibbosus. Mar Ecol Prog Ser 261:257-268

Warnau M, Bustamante P (2007) Radiotracer techniques: a unique tool in marine ecotoxicological studies. Environmental Bioindicators, Editorial, 2: 217-218

Warnau M, Teyssié J-L, Fowler SW (1996) Biokinetics of selected heavy metals and radionuclides in the common Mediterranean echinoid Paracentrotus lividus: sea water and food exposures. Mar Ecol Prog Ser 141:83-94

Weatherup RN, McCracken KJ (1998) Comparison of estimates of digestibility of two diets for rainbow trout, Oncorhynchus mykiss (Walbiaum), using two markers and two methods of faeces collection. Aquac Res 29:527-533

Weeks JM, Rainbow PS (1994) Interspecific comparisons of relative assimilation efficiencies for zinc and cadmium in an ecological series of talitrid amphipods (Crustacea). Oecologia 97:228-235

Whicker FW, Schultz V (1982) Radioecology: nuclear energy and the environment. CRC Press, Florida, USA

Wood CM (2011) An introduction to metals in fish physiology and toxicology. In: Wood CM, Farrell AP, Brauner CJ (ed) Fish physiology: homeostasis and toxicology of essential metals, Academic Press

Xu Y, Wang W (2002) Exposure and potential food chain transfer factor of Cd, Se and $\mathrm{Zn}$ in marine fish Lutjanus argentimaculatus. Mar Ecol Prog Ser 238:173-186

Yang D-Y, Chen Y-W, Gunn JM, Belzile N (2008) Selenium and mercury in organisms: interactions and mechanisms. Environ Rev 16:71-92

Zhang L, Wang W-X (2007) Size-dependence of the potential for metal biomagnification in early life stages of marine fish. Environ Toxicol Chem 26:787-794

Zhang L, Wang W-X (2006) Significance of subcellular metal distribution in prey in influencing the trophic transfer of metals in a marine fish. Limnol Oceanogr 51:20082017

Zhang L, Wang W-X (2005) Effects of Zn pre-exposure on Cd and Zn bioaccumulation and metallothionein levels in two species of marine fish. Aquat Toxicol 73:353-369 
Zhao X, Wang W-X, Yu KN, Lam PKS (2001) Biomagnification of radiocesium in a marine piscivorous fish. Mar Ecol Prog Ser 222:227-237 


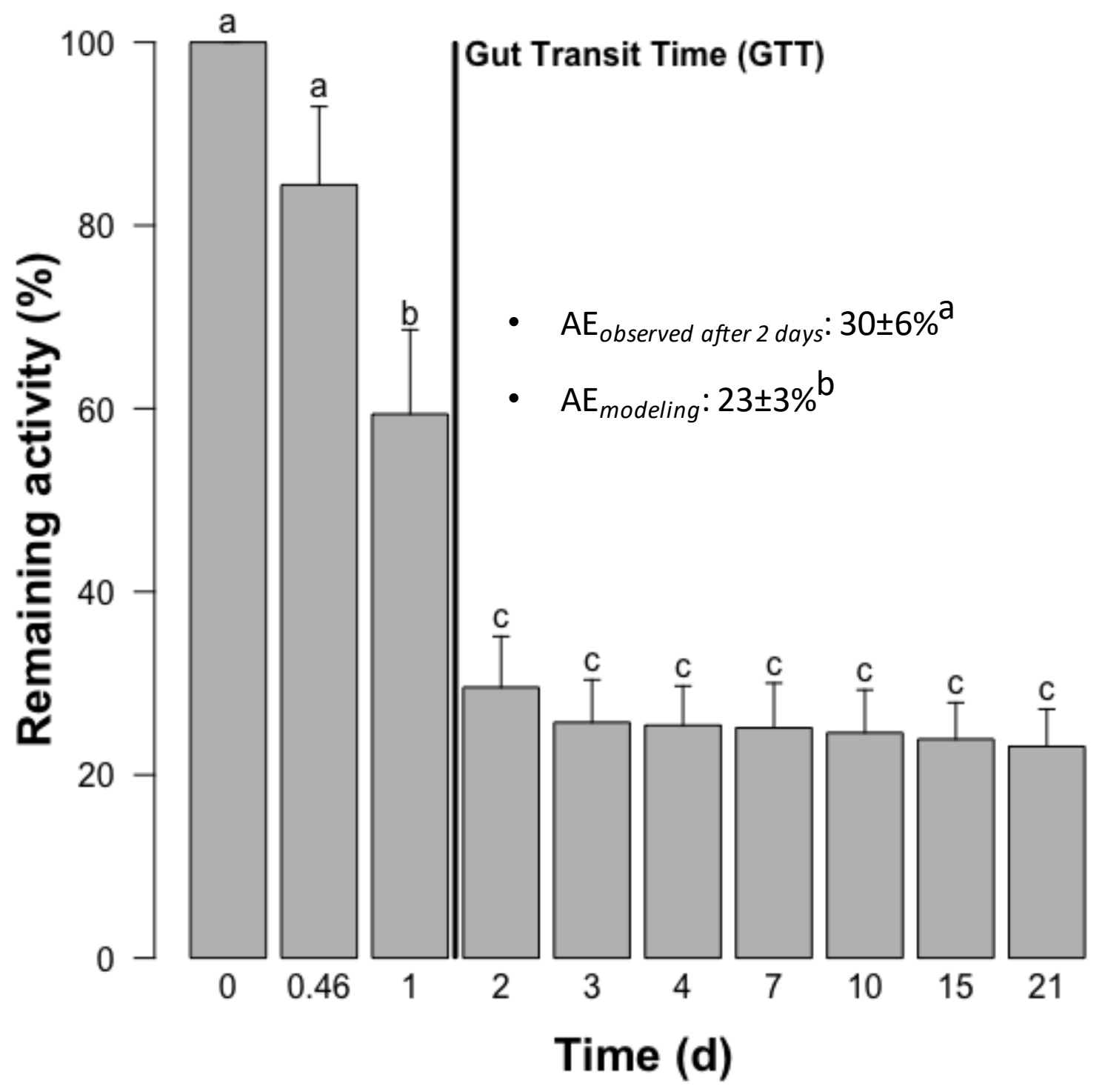

Figure 1. Remaining activities of ${ }^{54} \mathrm{Mn}$ during a 21-d depuration in turbot $(\mathrm{n}=12)$ fed radiolabelled with pellets. Data from Pouil et al. (2017b, supplementary material). For comparison, AE observed after 2 days of depuration ("short-term" approach) and AEs estimated using kinetic modeling ("long-term" approach) are indicated as bullet-points. Letters indicated significant differences $(\mathrm{p}<0.05)$ 


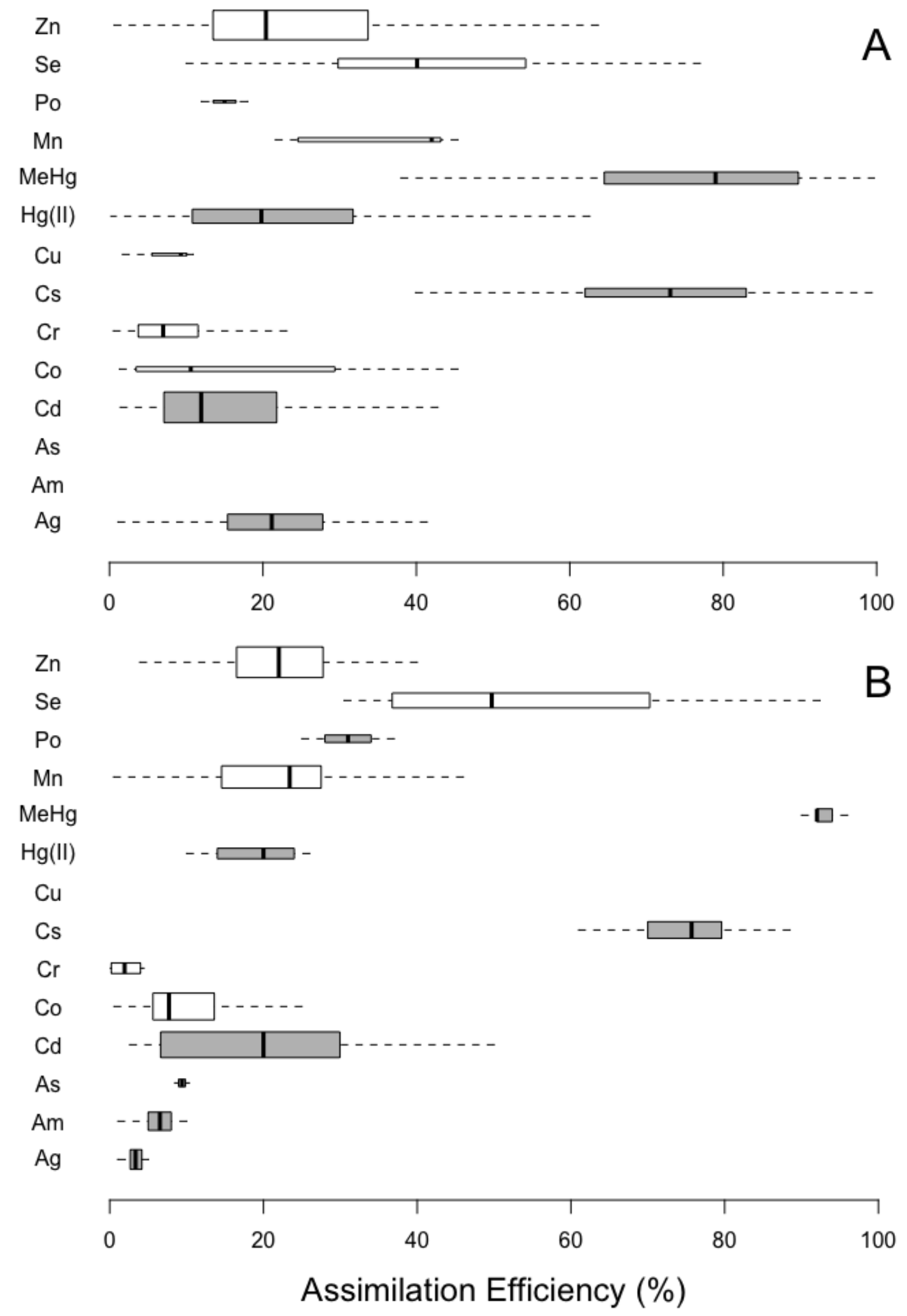

Figure 2. Comparison of AEs values of essential (white bars) and non-essential (grey bars) elements assessed in fish. Duration of experiments are either :(A) "short-term depuration" and (B) "long-term depuration" approaches. The width of the boxes is proportional to the number of observations. Extreme values are not represented. Data extracted from the literature are detailed in Tables 1 and 2 


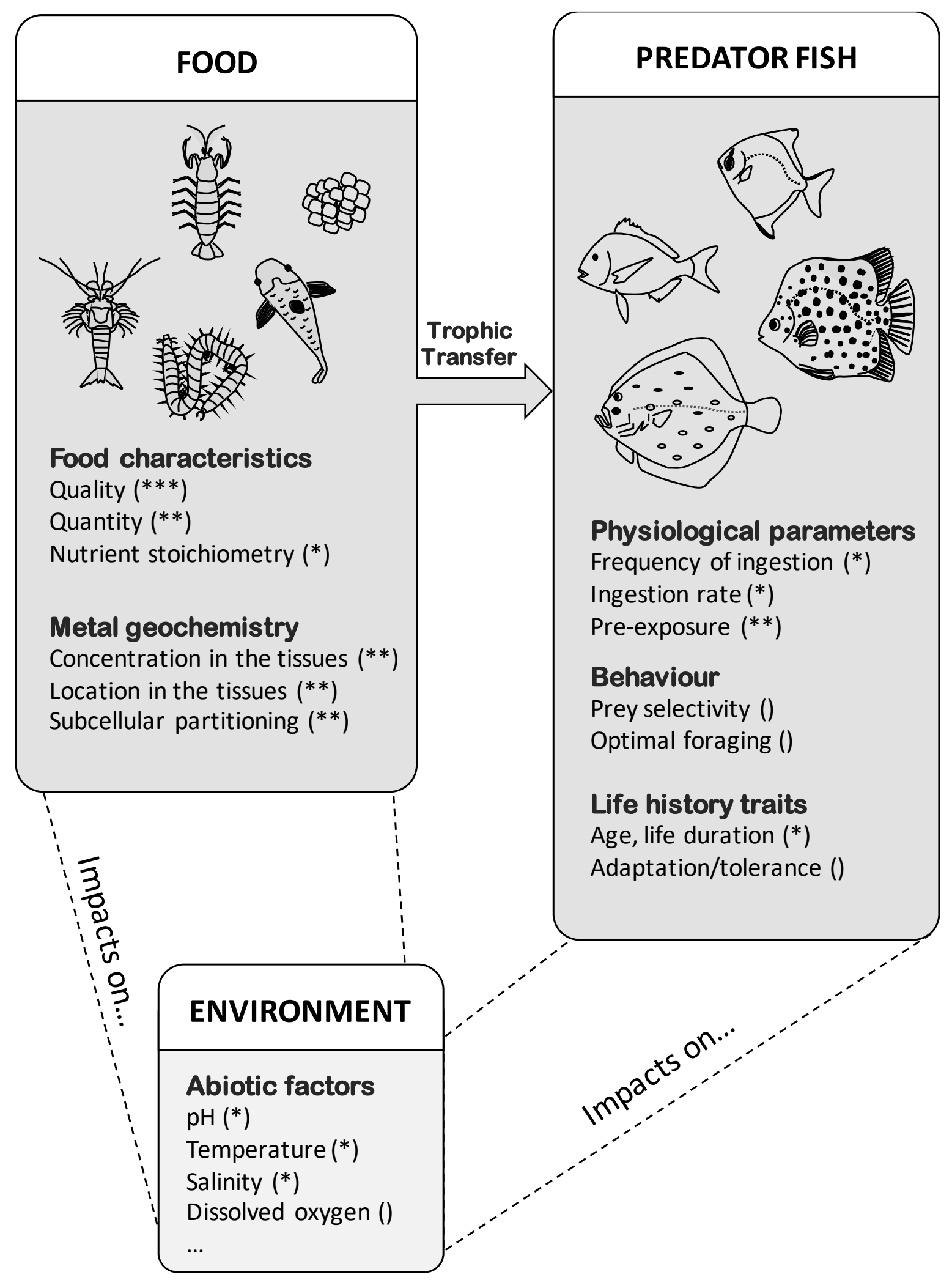

Figure 3. Schematic view of processes controlling the assimilation efficiency of metals in predator fish. The stars under brackets indicate the process already studied in the literature. Le number of stars is proportional to the quantity of information available in the literature. The absence of star indicates that the process is not yet investigated 
1 Table 1. Assimilation efficiencies of trace elements in freshwater and marine fish reported in experimental studies

\begin{tabular}{|c|c|c|c|c|c|c|}
\hline Species & Objectives & Metal & Food & Depuration (d) & $\mathrm{AE}(\%)$ & References \\
\hline Acanthopagrus schlegeli & $\begin{array}{l}\text { Allometry } \\
\text { Food composition } \\
\text { Trace element pre-exposure }\end{array}$ & $\begin{array}{l}\mathrm{Ag} \\
\mathrm{Cd} \\
\mathrm{Cu} \\
\mathrm{Hg}(\mathrm{II}) \\
\mathrm{Zn} \\
\end{array}$ & $\begin{array}{l}\text { Crustaceans } \\
\text { Crustaceans - Fish - Molluscs - Pellets } \\
\text { Crustaceans - Molluscs } \\
\text { Pellet } \\
\text { Crustaceans - Pellets } \\
\end{array}$ & $\begin{array}{l}2 \\
1.5-2 \\
2 \\
2 \\
1.5-2 \\
\end{array}$ & $\begin{array}{l}10-41 \\
2-38 \\
2-11 \\
3-55 \\
2-50 \\
\end{array}$ & $\begin{array}{l}\text { (Long and Wang 2005b) } \\
\text { (Wang et al. 2012) } \\
\text { (Zhang and Wang 2005) } \\
\text { (Zhang and Wang 2007) }\end{array}$ \\
\hline Ambassis urotaenia & $\begin{array}{l}\text { Interspecific comparison } \\
\text { Food composition }\end{array}$ & $\begin{array}{l}\mathrm{Cd} \\
\mathrm{Cr} \\
\mathrm{Zn} \\
\end{array}$ & $\begin{array}{l}\text { Crustaceans } \\
\text { Crustaceans } \\
\text { Crustaceans }\end{array}$ & $\begin{array}{l}1 \\
1 \\
1-2.1 \\
\end{array}$ & $\begin{array}{l}10-43 \\
1-10 \\
2-32 \\
\end{array}$ & (Ni et al. 2000) \\
\hline Amphiprion ocellaris & Water $\mathrm{pH}$ & $\begin{array}{l}\mathrm{Mn} \\
\mathrm{Zn}\end{array}$ & $\begin{array}{l}\text { Pellets } \\
\text { Pellets }\end{array}$ & $\begin{array}{l}20 \\
20 \\
\end{array}$ & $\begin{array}{l}1-10 \\
24-35\end{array}$ & (Jacob et al. in press) \\
\hline Cyprinodon variegatus variegatus & Pharmacokinetic model & $\mathrm{MeHg}$ & Phytoplankton - Pellets & $0.1-35$ & $38-100$ & (Leaner and Mason 2002) \\
\hline Cyprinus carpio & $\begin{array}{l}\text { Food composition and quantity } \\
\text { Water temperature }\end{array}$ & $\begin{array}{l}\mathrm{Cd} \\
\mathrm{Zn}\end{array}$ & $\begin{array}{l}\text { Insects - Oligochaetes - Molluscs } \\
\text { Insects - Oligochaetes - Molluscs }\end{array}$ & $\begin{array}{l}2 \\
2 \\
\end{array}$ & $\begin{array}{l}9-80 \\
20-97 \\
\end{array}$ & (Van Campenhout et al. 2007) \\
\hline Danio rerio & $\begin{array}{l}\text { Food composition } \\
\text { Trace element pre-exposure }\end{array}$ & $\begin{array}{l}\mathrm{Ag} \\
\mathrm{Cd} \\
\mathrm{Cr} \\
\mathrm{Zn}\end{array}$ & $\begin{array}{l}\text { Polychaetes } \\
\text { Crustaceans - Polychaetes } \\
\text { Crustaceans } \\
\text { Crustaceans } \\
\end{array}$ & $\begin{array}{l}3 \\
2.5-3 \\
2.5 \\
2.5 \\
\end{array}$ & $\begin{array}{l}1-7 \\
3-18 \\
2-47 \\
12-54 \\
\end{array}$ & $\begin{array}{l}\text { (Boyle et al. 2011) } \\
\text { (Liu et al. 2002) }\end{array}$ \\
\hline Dicentrarchus labrax & Food chain & $\begin{array}{l}\mathrm{Am} \\
\mathrm{Cd} \\
\mathrm{Co} \\
\mathrm{Cs} \\
\mathrm{Mn} \\
\mathrm{Se} \\
\mathrm{Zn}\end{array}$ & $\begin{array}{l}\text { Fish } \\
\text { Fish } \\
\text { Fish } \\
\text { Fish } \\
\text { Fish } \\
\text { Fish } \\
\text { Fish }\end{array}$ & $\begin{array}{l}24 \\
24 \\
24 \\
24 \\
24 \\
24 \\
24\end{array}$ & $\begin{array}{l}4-8 \\
14-31 \\
13-28 \\
76-82 \\
24-42 \\
52-76 \\
28-48\end{array}$ & (Mathews and Fisher 2008) \\
\hline Fundulus heteroclitus heteroclitus & $\begin{array}{l}\text { Food chain } \\
\text { Food composition } \\
\text { Subcellular control }\end{array}$ & $\begin{array}{l}\mathrm{As} \\
\mathrm{Cd} \\
\mathrm{Cr} \\
\mathrm{Hg}(\mathrm{II}) \\
\mathrm{MeHg} \\
\mathrm{Po}\end{array}$ & $\begin{array}{l}\text { Crustaceans } \\
\text { Crustaceans - Fish - Insects - Polychaetes } \\
\text { Crustaceans - Polychaetes } \\
\text { Crustaceans - Polychaetes } \\
\text { Crustaceans - Fish - Insects - Polychaetes } \\
\text { Crustaceans }\end{array}$ & $\begin{array}{l}9 \\
1-13 \\
9 \\
9 \\
1-13 \\
13\end{array}$ & $\begin{array}{l}9-10 \\
3-70 \\
0-4 \\
10-26 \\
47-96 \\
25-37 \\
\end{array}$ & $\begin{array}{l}\text { (Dutton and Fisher 2011) } \\
\text { (Seebaugh et al. 2005) } \\
\text { (Goto and Wallace 2009) } \\
\text { (Mathews and Fisher 2008) }\end{array}$ \\
\hline Gambusia affinis & $\begin{array}{l}\text { Food chain } \\
\text { Trace element pre-exposure }\end{array}$ & $\begin{array}{l}\mathrm{Hg}(\mathrm{II}) \\
\mathrm{MeHg}\end{array}$ & Crustaceans & $\begin{array}{l}6 \\
6 \\
\end{array}$ & $\begin{array}{l}25-78 \\
81-98 \\
\end{array}$ & (Pickhardt et al. 2006)6) \\
\hline Ictalurus punctatus & In-vitro digestion & $\mathrm{MeHg}$ & Polychaetes & 1.5 & $52-65$ & (Leaner and Mason 2002) \\
\hline Lepomis microlophus & $\begin{array}{l}\text { Food chain } \\
\text { Trace element pre-exposure }\end{array}$ & $\begin{array}{l}\mathrm{Hg}(\mathrm{II}) \\
\mathrm{MeHg}\end{array}$ & Crustaceans & $\begin{array}{l}6 \\
6 \\
\end{array}$ & $\begin{array}{l}0-18 \\
84-94\end{array}$ & (Pickhardt et al. 2006) \\
\hline Lutjanus argentimaculatus & $\begin{array}{l}\text { Food composition } \\
\text { Ingestion rate }\end{array}$ & $\begin{array}{l}\mathrm{Cd} \\
\mathrm{Cs} \\
\mathrm{Se} \\
\mathrm{Zn}\end{array}$ & $\begin{array}{l}\text { Crustaceans - Molluscs } \\
\text { Crustaceans - Fish - Molluscs } \\
\text { Crustaceans - Molluscs } \\
\text { Crustaceans - Molluscs } \\
\end{array}$ & $\begin{array}{l}3 \\
3 \\
3 \\
3 \\
\end{array}$ & $\begin{array}{l}4-33 \\
82-99 \\
27-60 \\
13-53 \\
\end{array}$ & $\begin{array}{l}\text { (Xu and Wang 2002) } \\
\text { (Zhao et al. 2001) }\end{array}$ \\
\hline Menidia $\mathrm{sp}$ & Food composition & $\begin{array}{l}\mathrm{Cd} \\
\mathrm{Co} \\
\mathrm{Se} \\
\mathrm{Zn}\end{array}$ & $\begin{array}{l}\text { Crustaceans } \\
\text { Crustaceans } \\
\text { Crustaceans } \\
\text { Crustaceans } \\
\end{array}$ & $\begin{array}{l}0.8 \\
0.8 \\
0.8 \\
0.8\end{array}$ & $\begin{array}{l}2-4 \\
1-3 \\
25-33 \\
4-8\end{array}$ & (Reinfelder and Fisher 1994) \\
\hline
\end{tabular}




\section{Table 1 (to be continued)}

\begin{tabular}{|c|c|c|c|c|c|c|}
\hline Species & Objectives & Element & Food & Depuration (d) & AE $(\%)$ & References \\
\hline Monodactylus argenteus & Interspecific comparison & $\begin{array}{l}\mathrm{Co} \\
\mathrm{Zn}\end{array}$ & $\begin{array}{l}\text { Crustaceans } \\
\text { Crustaceans }\end{array}$ & $\begin{array}{l}45 \\
45\end{array}$ & $\begin{array}{l}4-5 \\
14-16\end{array}$ & (Pouil et al. 2017a) \\
\hline Morone saxatilis & $\begin{array}{l}\text { Allometry } \\
\text { Food chain }\end{array}$ & $\begin{array}{l}\mathrm{Ag} \\
\mathrm{Am} \\
\mathrm{Cd} \\
\mathrm{MeHg} \\
\mathrm{Po} \\
\mathrm{Se} \\
\mathrm{Zn}\end{array}$ & $\begin{array}{l}\text { Crustaceans } \\
\text { Crustaceans } \\
\text { Crustaceans - Fish } \\
\text { Fish } \\
\text { Fish } \\
\text { Crustaceans } \\
\text { Crustaceans }\end{array}$ & $\begin{array}{l}13 \\
13 \\
2-14 \\
2 \\
2 \\
13-14 \\
13-14\end{array}$ & $\begin{array}{l}17-20 \\
5-7 \\
19-51 \\
82-94 \\
12-18 \\
31-47 \\
21-45\end{array}$ & $\begin{array}{l}\text { (Baines et al. 2002) } \\
\text { (Mathews and Fisher 2008) }\end{array}$ \\
\hline Periophthalmus modestus & $\begin{array}{l}\text { Food composition } \\
\text { Interspecific comparison } \\
\text { Salinity }\end{array}$ & $\begin{array}{l}\mathrm{Cd} \\
\mathrm{Cr} \\
\mathrm{Se} \\
\mathrm{Zn}\end{array}$ & $\begin{array}{l}\text { Crustaceans - Polychaetes } \\
\text { Crustaceans } \\
\text { Crustaceans - Polychaetes } \\
\text { Crustaceans - Polychaetes }\end{array}$ & $\begin{array}{l}1-2 \\
1-2 \\
1-2 \\
1-2\end{array}$ & $\begin{array}{l}2-31 \\
1-26 \\
32-40 \\
1-36\end{array}$ & $\begin{array}{l}\text { (Ni et al. 2000) } \\
\text { (Ni et al. 2005) }\end{array}$ \\
\hline Plectorhinchus gibbosus & Food composition & $\begin{array}{l}\mathrm{Hg}(\mathrm{II}) \\
\mathrm{MeHg}\end{array}$ & $\begin{array}{l}\text { Crustaceans - Fish } \\
\text { Crustaceans - Fish }\end{array}$ & $\begin{array}{l}1 \\
1\end{array}$ & $\begin{array}{l}6-32 \\
45-98\end{array}$ & (Wang and Wong 2003) \\
\hline Scatophagus argus & Interspecific comparison & $\begin{array}{l}\mathrm{Co} \\
\mathrm{Zn}\end{array}$ & $\begin{array}{l}\text { Crustaceans } \\
\text { Crustaceans }\end{array}$ & $\begin{array}{l}45 \\
45\end{array}$ & $\begin{array}{l}5-6 \\
23-25\end{array}$ & (Pouil et al. 2017a) \\
\hline Scophthalmus maximus & $\begin{array}{l}\text { Allometry } \\
\text { Food chain } \\
\text { Food composition } \\
\text { Interspecific comparison } \\
\text { Subcellular control } \\
\text { Water pH } \\
\text { Water temperature }\end{array}$ & $\begin{array}{l}\mathrm{Ag} \\
\mathrm{Am} \\
\mathrm{Cd} \\
\mathrm{Co} \\
\mathrm{Cs} \\
\mathrm{Mn} \\
\mathrm{Zn}\end{array}$ & $\begin{array}{l}\text { Pellet - Polychaetes } \\
\text { Fish } \\
\text { Fish - Pellets } \\
\text { Crustaceans - Fish - Pellets - Polychaetes } \\
\text { Fish } \\
\text { Crustaceans - Fish - Pellets - Polychaetes } \\
\text { Crustaceans - Fish - Pellets - Polychaetes }\end{array}$ & $\begin{array}{l}21 \\
21 \\
21 \\
21 \\
21 \\
21 \\
21\end{array}$ & $\begin{array}{l}0-4 \\
6-10 \\
6-42 \\
1-45 \\
61-65 \\
22-46 \\
13-33\end{array}$ & $\begin{array}{l}\text { (Mathews et al. 2008) } \\
\text { (Pouil et al. 2015) } \\
\text { (Pouil et al. 2016) } \\
\text { (Pouil et al. 2017b) } \\
\text { (Pouil et al. in press) }\end{array}$ \\
\hline Scyliorhinus canicula & Interspecific comparison & $\begin{array}{l}\mathrm{Am} \\
\mathrm{Cd} \\
\mathrm{Co} \\
\mathrm{Cs} \\
\mathrm{Mn} \\
\mathrm{Zn}\end{array}$ & $\begin{array}{l}\text { Fish } \\
\text { Fish } \\
\text { Fish } \\
\text { Fish } \\
\text { Fish } \\
\text { Fish }\end{array}$ & $\begin{array}{l}21 \\
21 \\
21 \\
21 \\
21 \\
21\end{array}$ & $\begin{array}{l}5-7 \\
25-33 \\
8-14 \\
69-77 \\
24-30 \\
16-18\end{array}$ & (Mathews et al. 2008) \\
\hline Sebastiscus marmoratus & Food composition & Cs & Molluscs & 2.75 & $62-83$ & (Pan and Wang, 2016) \\
\hline Siganus canaliculatus & $\begin{array}{l}\text { Food composition } \\
\text { Starvation }\end{array}$ & $\begin{array}{l}\mathrm{Cd} \\
\mathrm{Cr} \\
\mathrm{Zn}\end{array}$ & $\begin{array}{l}\text { Macroalgae } \\
\text { Macroalgae } \\
\text { Macroalgae }\end{array}$ & $\begin{array}{l}2 \\
2 \\
2\end{array}$ & $\begin{array}{l}2-47 \\
3-24 \\
4-42\end{array}$ & (Chan et al. 2003) \\
\hline Siganus fuscescens & Food composition & Cs & Macroalgae - Molluscs & 2.75 & $40-67$ & (Pan and Wang, 2016) \\
\hline Sparus aurata & $\begin{array}{l}\text { Food chain } \\
\text { Interspecific comparison }\end{array}$ & $\begin{array}{l}\mathrm{Am} \\
\mathrm{Cd} \\
\mathrm{Co} \\
\mathrm{Cs} \\
\mathrm{Mn} \\
\mathrm{Se} \\
\mathrm{Zn}\end{array}$ & $\begin{array}{l}\text { Crustaceans - Fish } \\
\text { Crustaceans - Fish } \\
\text { Crustaceans - Fish } \\
\text { Crustaceans - Fish } \\
\text { Crustaceans - Fish } \\
\text { Crustaceans } \\
\text { Crustaceans - Fish }\end{array}$ & $\begin{array}{l}15-21 \\
15-21 \\
15-21 \\
15-21 \\
15-21 \\
15 \\
15-21\end{array}$ & $\begin{array}{l}1-9 \\
6-50 \\
7-23 \\
71-89 \\
11-28 \\
61-92 \\
4-25 \\
\end{array}$ & $\begin{array}{l}\text { (Mathews and Fisher 2008) } \\
\text { (Mathews et al. 2008) }\end{array}$ \\
\hline
\end{tabular}




\begin{tabular}{|c|c|c|c|c|c|c|}
\hline Terapon jarbua & $\begin{array}{l}\text { Food composition } \\
\text { Trace element pre-exposure } \\
\text { Subcellular control }\end{array}$ & $\begin{array}{l}\mathrm{Ag} \\
\mathrm{Cd} \\
\mathrm{Cs} \\
\mathrm{Hg}(\mathrm{II}) \\
\mathrm{MeHg} \\
\mathrm{Se} \\
\mathrm{Zn}\end{array}$ & $\begin{array}{l}\text { Crustaceans } \\
\text { Crustaceans - Fish - Molluscs } \\
\text { Molluscs } \\
\text { Fish - Molluscs } \\
\text { Fish - Molluscs } \\
\text { Crustaceans - Molluscs } \\
\text { Crustaceans - Fish - Molluscs }\end{array}$ & $\begin{array}{l}2 \\
1.5-2 \\
2-2.75 \\
2 \\
2 \\
1.5 \\
1.5\end{array}$ & $\begin{array}{l}12-41 \\
2-41 \\
65-83 \\
12-100 \\
52-97 \\
10-63 \\
1-67\end{array}$ & $\begin{array}{l}\text { (Dang and Wang 2010) } \\
\text { (Long and Wang 2005a) } \\
\text { (Pan and Wang, 2016) } \\
\text { (Zhang and Wang 2006) }\end{array}$ \\
\hline
\end{tabular}

